Chapter 4

\title{
Integration of Allelopathy to Control Weeds in Rice
}

\author{
T.D. Khanh, L.H. Linh, T.H. Linh, N.T. Quan, \\ D.M. Cuong, V.T.T. Hien, L.H. Ham, K.H. Trung and \\ T.D. Xuan
}

Additional information is available at the end of the chapter

http://dx.doi.org/10.5772/56035

\section{Introduction}

Rice (Oryza sative L.) is the main food crop in Asia and the staple food of the majority of the population in many regions of the world. The population pressure in rice-consuming countries demands that more attention be directed towards new approaches to sustainable rice production. Improvement of both crop quality and yield is an urgent task [1]. Optimally, rice yield improvement must be sought through agronomic approaches that are environmentally safe [2]. Weed management using allelopathy may effect a yield improvement without environmental cost, which is one of the most important considerations for worldwide scientists working to secure the world's food supply for future generations.

Allelopathy is described as the ability of plants to inhibit or stimulate growth of other plants in the environment by exuding chemicals. The concept of allelopathy was first raised by Hans Molisch to describe both the beneficial and the detrimental chemical interactions of plants and microorganisms [3]. Since then, the term "allelopathy" has undergone several changes and it has been described as any direct or indirect harmful or beneficial effects of one plant on another through the production of chemical compounds that it releases into the environment [4]. The subject of allelopathy currently receives much attention from scientists; the increasing interest in allelopathy in recent years has been stimulated by the recognition that agro-ecological applications of allelopathy may provide alternatives to synthetic herbicides for weed management [5] and with the evidence that allelopathy has the potential for weed control [6-7].

The overuse of agrochemicals has caused environmental degradation, pest tolerance and human health concerns. Agriculture worldwide is currently using about 3 million tons of herbicides annually, and herbicide-resistant weeds have become more prolific, which has further expanded the use of herbicides [8]. To solve these problems, it is necessary to develop 
sustainable weed management systems that may reduce both herbicide dependency and the burden of manual weeding. With attempts to exploit rice's allelopathic properties for weed control in rice growing, research into rice allelopathy was begun in the early 1970s and has been widely studied in the USA, Europe, Japan, Korea, India and China. If the allelopathic property of crops can be improved, it implies that the competitive ability of crops against weeds can be strengthened, the amount of applied herbicides lowered and environmental risks reduced. Improved crops' allelopathic potential may be useful for rice and all other crops [9]. Crop allelopathy may be a successful tool to manage weed infestations in agricultural production, if it can be exploited appropriately in a rotational cropping system [10]. However, in the case of rice, it is difficult to rotate different crops in a paddy field; therefore, enhancing weed suppression by rice itself may be among the most feasible means of controlling weeds. The isolation and identification of allelochemicals responsible for weed suppression by rice plants may be helpful for understanding the chemical interactions of rice. The introduction of allelopathic traits into cultivated rice via a breeding program may give the possibility of utilizing rice allelopathy in agricultural production.

The aims of this chapter are to present some aspects of integration of allelopathy to control weeds in rice that is pertinent to sustainable agriculture. The following points are discussed: (i) role of allelopathy in weed management; (ii) methodology of allelopathy utilization in rice; (iii) incorporation of higher plants with strong allelopathy to control weeds; (iv) developing allelochemicals and their derivatives for weed management; (v) effort to utilize rice allelopathy for rice weed control; (vi) benefits from allelopathy integrated into sustainable agriculture.

\section{Rice weeds}

Weeds cause major yield losses in crops and also reduce their quality. Without weed management, rice yield may be reduced by 16 to $86 \%$, or even $100 \%$ [11]. Worldwide more than 1000 weed species have been reported in rice [12]. However, 13 species are the most serious weeds spp.: Cyperus rotundus L. (purple nutsedge), Cynodon dactylon (L.) Pers. (Bermunda grass), Echinochloa crus-galli (L.) Beauv (barnyardgrass), Echinochloa colonum (L.) Link. (jungle rice), Eleusine indica (L.) Gaertner (goosegrass), Eichhornia crassipes (Mart.) Solms (water hyacinth), Portulaca oleracea L. (purslane), Chenopodium album L. (lambsquarter), Digitaria arvensis L. (field bindweed), Sorghum halepense (L.) Pers. (Johnson grass), Imperata cylindrical (L.) Beauv. (spear grass), Avena fatua L. (wild oat), and Amaranthus retroflexus L. (redroot pigweed) [13-14]. The type of weed species to infest mainly depends on weather, temperature and latitude, and where the rice crop is grown. For instance in Australia, Cyperus difformis L. (dirty dora), Elatine gratioloides (waterwort), D. minus (starfruit) and E. crus-galli (L.) Beauv. (barnyardgrass) are major noxious weeds [15] (Table 1). The overuse of herbicides results in herbicide resistance in weeds, which cause more difficulties in weed management. Approximately 200 weed biotypes from 125 different species worldwide have become resistant to herbicides [16]. Traditional weed management in rice was dependent on weather, water coverage and hand weeding. These methods are time-consuming and labor intensive, hence, current weed control depends on synthetic herbicides, but these are harmful to the environ- 
ment and humans. Therefore, a new strategy for biological weed management in sustainable agriculture should be developed.

\begin{tabular}{ll}
\hline Botanical and common name & \\
\hline Ammannia spp (Redstems) & Jussiaea decurrens Walt.(Winged waterprimrose) \\
Brachiaria mutica Forssk(Bufallo grass) & Marsilea quadrifolia L. (Waterclover) \\
Bacopa spp.(Waterhyssops) & Monochoria vaginalis Burm.f.(Monochoria) \\
Cyperus iria. L (Ricefield flatsedge) & Murdannia nudiflora L.(Nakedstem dewflower) \\
Cyperus difformis.L (Dirty-dora) & Murdannia keisak Hassk. (Wartremoving herb) \\
Commelina diffusa. Burm (Dayflower) & Ischaemum rugosum Salisb (Wrinkle grass) \\
Dopatrium junceum Roxb Hamilt (Horsefly's eye) & Lindernia pyxidaria L. (Lindern) \\
Dactyloctenium aegyptium L. Beauv (Crowfoot grass) & Leptochloa chinensis L. Nees ( Red spangletop) \\
Echinochloa colonum L. Link ( Shama millet) & Paspalum distichum L.(Knotgrass) \\
Echinochloa crus-galli L. Beauv (Barnyardgrass) & Leptochloa fascicularis Lam.(Sprangletop) \\
Eleocharis acicularis L. Roemer (Needle spikerush) & Rotala indica Wild. (India toothcup) \\
Elatine triandra Schkuhr (Waterwort) & Sagittaria longiloba Engelm. (Arrow head) \\
Fimbristylis dichotoma L. Vahl (Forked fimbry) & Sphenoclea zeylanica Gaertin (Gooseweed) \\
Fimbristylis miliacea L. Vahl (Grasslike fimbry) & Scirpus mucronatus L.(Bulrush) \\
Isachne globosa Thumb (Chigozasa) & Salvinia molesta Mitchel.(Kariba weed) \\
Heteranthera limosa Sw.Willd (Ducksalad) & Scirpus juncoides Ferm(Weakstalk bulrush) \\
\hline
\end{tabular}

Table 1. List of major rice weeds in paddy field

\section{Role of allelopathy in weed management}

Agriculture worldwide has struggled to control weed interference and the appearance of herbicide-resistant weeds that require the development of new herbicides, and increasing doses of synthetic herbicides in practice. There are about 30000 species of weeds affecting food crops, which cause great losses of crop yields worldwide [17]. In the USA alone, about \$20 billion worth of crops are lost each year, accounting for 10\% of production [18]. Many highyield crops have been bred, but this simultaneously increases the heavy dependence on agrochemicals. The desire for safer control of weeds with less environmental impact has become a worldwide concern. In this regard, integrating allelopathy can be a source of new methods for sustainability of agriculture systems.

\section{Weed control by allelopathy}

Weeds compete with crops for nutrients, water, space, and requirements for photosynthesis, which reduces crop yield. Synthetic herbicides can control weeds effectively and reduce labor in weeding but can cause numerous detriments to the environment and humans, and increase 
the occurrence of herbicide-resistant weeds. Since it is known that plants can self-regulate their densities and distribution in nature via allelopathic interactions, scientists have attempted to exploit these characteristics of crops and weeds in agriculture. The use of allelopathy for biological control of weeds in agriculture practice has attracted the interest of many agronomic scientists [1].

One approach of utilizing the allelopathic property of crops is to screen accessions to examine their potential for weed suppression $[11,19]$. To place crops in a more favourable competitive position in relation to allelopathy over weeds is important for the establishment of sustainable agriculture [20]. The strategy for using allelopathy for weed management could be either through directly exploiting natural allelopathic interactions, especially of crop plants, or applying allelochemicals as a source of natural herbicides. Derivatives of allelochemicals from plants used as herbicides with environmental properties include mesotrione [21-22] and citronella and bilanaphos oil [21]. Several microbial allelochemical products are marketed worldwide, such as glufosinate and bialaphos.

\section{Methodology of allelopathy utilization}

\subsection{Crop rotation}

Crop rotation is one of the traditional practices whereby some crops, particularly leguminous species, are grown in short rotation with the main crops [1]. Crop rotation implies growing different crops in systematic and recurring sequence on the same land. This rotational system can help minimize the interference of weeds, fungi, pathogens, insects, and nematodes, and improve soil physical properties, fertility, and organic matter content and reduce soil erosion and heal soil sickness, and crop yields are therefore increased. Allelopathy and crop selection may play a key role in management strategies of weeds and pests. Use of allelopathy in a cropping system relies on better knowledge of the chemicals involved and their behaviour in the agro-ecosystem [23]. Lampkin, 1994 [24] suggested that the principles of selecting crops for rotational sequences should be: (i) alternating between autumn and spring germinating crops, (ii) rotating between annual and perennial crops, (iii) replacing between closed and dense crops, which shade out weeds and open crops such as maize (Z. mays), which encourage weeds, and (iv) cutting or topping operations (in particular the traditional cleaning crops, leys, and green manures). Some reports indicated that rotation of maize-cowpea and maizesoybean gave higher yield than monoculture, and the nutrient status of soil was also improved [25-26]. Rotating tobacco-rye grass-maize could minimize the root rot diseases caused by a soil-borne pathogen [27]. This may be the result of the fungitoxins produced by rye grass that inhibited the germination of conidia or chlamydospores of Thielaviopsis basicola [28]. Johnson, 1985 [29] conducted a series of exhaustive field trials to determine the suitability of various non-host/poor-host plants for various cropping systems of sweet corn-soybean-wheatsoybean-spinach (Spinacia oleracea) that showed significant control of Meloidogyne incognita infestation. Furthermore, Rizvi and Rizvi, 1992 [30] demonstrated that some food crops such as wheat, barley, rye, maize, and triticale (Triticosecale wittmack) with high concentrations of 
gramine or hyroxamic acids were useful for controlling fields with high aphid populations. Allelochemical interactions of plants-plants, plants-soils, plants-micro-organisms, and plant residues from a crop rotation play an active role in enhancing crop yields. Those allelochemicals released from rotated crops then interacted with many physiological processes, which could help promote the growth and yield of crops. If plants used in a rotational system can be determined appropriately, the amount of chemical nitrogenous fertilizers is lowered and environmental hazard is reduced, whereas the sustainability of agriculture by substituting them with biologically fixed nitrogen from legumes is enhanced [31]. However, at present, negligible work has been done on the mode of action of allelochemicals in crop rotation, maybe due to their complicated transformation in nature. Moreover, Chou et al 1980 [77] reported $25 \%$ reduction in rice yield of second crop in Taiwan due to the phytotoxins produced during the decomposition of rice residues of first crop left in the soil. The phytotoxic effects of decomposing rice residues in the soil on the succeeding crop are problematic in some countries. In Southeast Asia, rotational systems give greater rice yield than rice monoculture and use of appropriate crops can also minimize the weed biomass significantly. In general, legume crops are preferred as preceding crops to suppress the weeds in succeeding rice crops [1].

\subsection{Cover crops, green manure, mulch and intercropping}

The term 'cover crop' is defined as crops cultivated with regular cropping for soil and moisture conservation, promotion of nutrient recycling, biomass production, temperature lowering, nuisance weed inhibition, and forage supply [32, 33, 34]. Cover crops may be referred to as either green manure crops or sometimes implied catch crops [35]. Popular allelopathic crops used as cover crops are: barley (Hordeum vulgare), sorghum (Sorghum spp.), maize (Z. mays), wheat (T. aestivum), rye (S. cereale), buckwheat. (Fagoprum esculentum), velvetbean (M. pruriens), crimson clover (Trifolium incarnatum), subterranean clover (Trifolium subterraneum), hairy vetch (Vicia vilosa) sweet potato (I. batatas), and convolvulaceae (Tricolor batatas) [32]. These allelopathic plants exhibited significant weed reduction [36-37]. Excluding phytotoxins released from cover crops into soil, shading effects of the cover crops as well as their thick and dense population, and fast growth could effectively suppress weeds [38]. Legume species and some cruciferous plants could improve soil fertility contributing organic matter and nitrogen to the soil. Successfully established cover crops can develop sufficiently dense canopies in the autumn to interfere with growth of perennial and winter annual weeds [39]. Application of green manure crops can enhance soil organic matter and reduce weed growth. Some plants are used as green manures, including: Mucuna spp., Canavalia spp., Trifolium spp., Brassica spp., and Ipomoea spp. [32]. Several non-leguminous plants belonging to the family of Brassicaceae, such as field mustard (Brassica campestris), white or yellow mustard (Brassica hirta), brown/ Indian mustard (Brassica nigra), rapeseed/soilseed rape/canola (B. napus), black mustard (B. nigra), and garden cress (L. sativum), were promising sources of green manure and significantly reduced weed biomass [40-41]. Among crops used for covering and green manure, leguminous species should be given priority as they provide rich nutrients including nitrogen to soil [42].When bracken fern (Pteridium aquilinum) was used as a green manure, it showed significant herbicidal and fungitoxic activities [43]. The integration of a cover crop into a cropping system 
by relay cropping, over- seeding, inter-seeding, and double cropping may be useful to supply nitrogen for grain crops and reduce soil erosion and interference of weeds [44]. Some secondary metabolites from cover crops such as volatile glucosinolates and the breakdown isothiocyanates, nitriles, epithinitriles, and ionic thiocyanates were responsible for weed and fungi inhibitory activities [45]. When plants with different growth habits and morphology are intercropped, weed biomass can be lowered. For instance, in maize, mung bean provides more weed suppression than peanut [46]. Barley, rye, and Vicia faba were planted in monoculture after the harvest of summer crop [47]. Barley+ V. faba and rye+ V. faba showed effective weed suppression. This was explained by the release of allelochemicals from root exudates during crop growth and from decomposing crop residues [47].

\section{Incorporation of higher plants with strong allelopathy to control weeds in rice}

\subsection{Direct use of plant materials in rice fields}

Many plants in the plant ecosystem exert significant allelopathic potential, and when they were incorporated into paddy fields, it resulted in excellent weed reduction. Our research, conducted during 1999-2006, was mainly exploring allelopathic potential of plants in Southeast Asia and Japan for paddy weed control. The preliminary screening for the allelopathic potential of plants in the plant ecosystem should be made with the following requirements: (i) an assessment of their invasiveness and area in the plant ecosystem; (ii) ensuring the plants have less natural weed density in their canopy and surroundings than other plants in their ecosystem; and (iii) using those are traditionally used as green manure, weed or pest management by local farmers [48-49]. Minimizing the hazardous impacts of pesticides (herbicides, insecticides, nematicides and fungicides) in agriculture is the current trend in modern agriculture. Many plants with strong allelopathic properties inhibited the growth of indicator test plants in our laboratory and greenhouse studies. Afterwards, plant species with strong weed suppression were examined against weeds grown in paddy fields. The direct incorporation of allelopathic plant materials into rice fields remarkably reduced the weed interference [48-49].

Southeast Asia has a rich diversity in plant ecosystems; hence, we tested a few hundred plants. More than 30 species including crops strongly inhibited the emergence of pathogens and weeds. In a preliminary investigation, we separated leaves, stems and roots of plants to test their effects on germination and growth of indicator plants (lettuce, radish) and noxious weeds in paddy fields [E. crus-galli (barnyardgrass) and Monochoria vaginalis (monochoria)] in bioassays and in greenhouse trials. In field trials, some plant species reduced weeds and increased the rice yield (Table 1). We suggested that these plants could be used as source of natural herbicides. 


\begin{tabular}{|c|c|c|}
\hline Plant species & Weed reduction $(\%)$ & $\begin{array}{l}\text { Increased in rice yield } \\
\text { ton } / \mathrm{ha}^{-1}\end{array}$ \\
\hline Ageratum conyzoides L. (billy goat weed) & 80.8 & 20.9 \\
\hline Alocasia cucullata (Chinese taro) & 78.4 & 17.0 \\
\hline Azadirachta indica A.Juss (neem) & $91.0^{*}$ & - \\
\hline Bidens pilosa L.(Beggar tick) & 81.8 & 23.3 \\
\hline Blechnum orientale L.(White fern) & 74.7 & 23.3 \\
\hline Eupatorium canabium L.(Fragrant thoughoutwork) & 75.8 & 23.3 \\
\hline Euphobia hirta L. (Asthma weed) & 87.9 & 23.3 \\
\hline Helianthus tuberosus (Jerusalem artichoke) & 77.8 & 17.0 \\
\hline Galactia pendula Pers (Galactia) & 84.8 & 7.0 \\
\hline Fagopyrum esculentum Moench (Buckwheat) Pellets & 70.0 & - \\
\hline Leucaena glauca L.(White lead-tree) & 85.9 & 23.3 \\
\hline Melia azedarach L.(Chinaberry) & 86.9 & 4.7 \\
\hline Nerium odeander (Oleander) & 74.5 & 19.5 \\
\hline Medicago sativa L. (Alfalfa) Pellets & 70.0 & - \\
\hline cv. Rasen & 80.0 & 80.6 \\
\hline cv. Yuba & 65.0 & 29.0 \\
\hline Morus alba L. (Mulberry) & 72.7 & 23.3 \\
\hline \multicolumn{3}{|l|}{ O. sativa L. (Rice) } \\
\hline Hulls & 51.7 & 19.4 \\
\hline Bran & 25.1 & $-6.5^{*}$ \\
\hline Hulls +Rasen & 88.3 & 77.4 \\
\hline Bran+Yuba & 53.1 & 29.0 \\
\hline Piper methysticum (Kava) & $86.3^{*}$ & - \\
\hline Passiflora incarnate (Passionflower) & 75.1 & 21.5 \\
\hline Passiflora edulis (Passionflower) & 72.7 & 34.5 \\
\hline Sophora japonica (Japanese pagoda tree) & 84.1 & 9.9 \\
\hline Stylosanthes guianensis (Stylo) & 72.0 & 25.8 \\
\hline Tephrosia candela L. (White tephrosia) & 91.9 & 23.3 \\
\hline Herbicide $(5 \mathrm{~L} \text { ha- } 1)^{\star *}$ & 77.8 & 11.6 \\
\hline Hand weeding & 71.7 & 25.6 \\
\hline
\end{tabular}

(-) Calculation was not conducted; Inhibited compared with the control, applied dose: 1-2 tons ha-1; *: only greenhouse trial was conducted; ** : active ingredients in herbicides: pyributicard, bromobutide, butanamide, benzofenap [Shizetto furoaburu (5 L ha-1), Sankyo Ltd., Japan], and butachlor (600 g L-1 (Butataf, Monsato company, UK). Source: [48, 50].

Table 2. Allelopathic plants inhibitory to paddy weeds and stimulatory to rice yields over their control 


\subsection{Dose of application}

The application of 1-2 tons ha-1 biomass of alfalfa (Medicago sativa), buckwheat (Fagopyrum esculentum), kava (Piper methysticum), neem (Azadirachta indica), leucaena (Leucaena glauca), billy goat weed (Ageratum conyzoides), galactia (Galactia pendula), chinaberry (Melia azedarach), frangrant thoroughwort (Eupatorium canabium) and passion fruit (Passiflora edulis), strongly reduced the growth of major paddy weeds including E. crus-galli, M. vaginalis, Rotala indica, Cyperus difformis, Digitaria ciliaris [50-54]. Plant species exhibiting suppression $>20 \%$ were selected for weed control. Plant materials applied $<1$ ton ha ${ }^{-1}$ suppresses only weed emergence. The application of alfalfa plants and its pellets or buckwheat pellets at 1-2 tons ha-1 caused significant reduction in weeds. The magnitude of weed reduction in rice fields was proportional to the applied dose of plant materials. However, it should not exceed 2 tons ha $^{-1}$, because application of higher rates causes practical problems for its application, etc. [48]. Despite drastic suppression of paddy weed biomass, the allelopathic plants did not injure the rice plants, rather enhanced their yields by $20 \%$ (Table 2). The magnitude of weed inhibition depended on applied plant species. The nutrients released from the plants applied to paddy fields increased the rice yields.

\subsection{Methods of application}

The ability of allelopathic plants to reduce weeds in paddy fields depends on the treatment method. The plants with strong weed suppressing ability in the screening should be exploited for paddy weed control [51,53-54]. The leaves of the screened plants are commonly used to provide a large biomass; however, their nutrient contents should be monitored before conducting field trials. Spreading plant materials evenly on the surface of paddy field, 1-5 days after saturating with water at 1 ton ha-1 causes greatest weed biomass reduction. Application of allelopathic materials in fields, 7 days after adding water did not influence paddy weed emergence. Major paddy weeds (E. crus-galli and $R$. indica) re-emerged in treatments with alfalfa pellets, alfalfa plants, rice hulls and rice bran [52, 55]. A sequential application of biomass was also studied. In the first application, 1 ton ha ${ }^{-1}$ allelopathic material was added 1-2 days after irrigating the paddy soils. In the second and third applications, the same doses were added at 10 days intervals. Each application caused an additional 10-15\% inhibition of weeds. However, a greater amount of plant material was needed, which requires more fieldwork, hence, becomes costly [48, 53, 56-57].

\section{Developing allelochemicals and their derivatives to control weeds in rice}

\subsection{Role of allelochemicals in paddy fields}

The allelochemicals released from the plants incorporated into paddy soil play a crucial role in inhibiting the paddy weed growth. Many weed growth inhibitors identified from M. sativa, Piper methysticum, A. indica (neem), A. conyzoides, O. sativa, and B. pilosa belong to phenolic acids [52,56, 58-63], fatty acids [56], lactones [62-63], and amino acids [64]. These compounds 
inhibit the paddy weed growth at low concentrations in bioassays. However, the evidence of how these growth inhibitors act in paddy field conditions has remained unclear. We also examined the correlation of inhibitory potential of plant materials [alfalfa ( $M$. sativa) and kava (P. methysticum)] incorporated in paddy soil against weeds [60]. Both alfalfa and kava strongly inhibited barnyardgrass and monochoria (M. vaginalis) growth up to 10 days after incorporation (80-100\% weed control) and suppression persisted for $20-25$ days (50\% weed control). Many phenolic acids were found in the soil even after 50 days in low concentration, but their concentrations was maximized at 10-15 days and were efficacious until 20-25 days after incorporation. Some growth inhibitors found in the kava treatment showed strong inhibition until 25 days after application, these may be lactones (major constituents in kava roots) and are plant and fungal growth inhibitors [63].

Observations from laboratory, greenhouse and field trials showed that the effects of plant materials on weed species are selective [48]. Different plant materials may possess different quantities and types of toxins, of which the amount released into soil after incorporation, is also species dependent. Despite the identification of many growth inhibitors, their fates after penetrating the soil, how they accumulate at phytotoxic levels and influence the weed growth, the interaction of these compounds with soil factors such as nutrients, $\mathrm{pH}$, minerals and soil microbes, have not yet been fully understood. Even though these issues are complex, we need to understand the actual mode of action of allelochemicals in the environment, so that their efficacies can be increased and become more helpful to develop novel bioactive herbicides.

\subsection{Syntheses of novel compounds}

Searching the growth inhibitors from plants and testing their efficacies against weeds in the laboratory, greenhouse and fields are just the initial steps to developing bioactive herbicides. However, it is necessary to develop bioactive herbicides, because: (i) direct use of allelochemicals as herbicides is not successful as these compounds are degraded in nature, before reaching the targets, (ii) to isolate allelochemicals from plants is complex, promising compounds for weed suppression exist in low quantities in plants, hence, it is too costly to use as herbicides and (iii) despite the promising weed reduction by direct application of plant materials to paddy soils, it requires a very high amount of plant biomass, therefore, does not meet the current requirements of trend in agricultural production in many countries. However, despite obtaining numerous compounds with herbicidal activities, very few constituents from plants have been marketed as herbicides than from bacteria and fungi [65]. Further, most reported secondary metabolites with strong herbicidal activity have complex chemical structures, hence, may not be processed as novel herbicides, because of difficulties in their synthesis and thus become costly. Thus searching for compounds having a simple form with strong herbicidal activities should be a priority. The synthesis of compounds derived from allelochemicals, attached with further functional groups and possessing herbicidal activities, is indispensable to developing novel bioactive herbicides.

Dihydro-5,6-dhydrokawain (DDK) (Figure 1) is a major compound in all parts of Alpinia (Alpinia zerumbet), a plant distributed widely in the subtropics and tropics. Besides many promising pharmaceutical efficacies, DDK exerts herbicidal and antifungal activities in 
bioassay trials. Our team has synthesized numerous DDK derivatives (Figure 1) [66] and tested for their influences against indicator plant and plant fungi. The derivative dimethyl phosphorothionate exhibited maximum antifungal activity of $91 \%$ and $72 \%$ against Corticium rolfsii and Pythium spp., respectively [67]. Twenty-four kinds of esters were made from cinnamic acid, p-coumaric acid and ferulic acid, alcohols and the components of Alpinia [68]. Among these derivatives, isopropyl 4-hydroxycinnamate and butyl 4-hydroxy-cinnamate were fungitoxic to Pythium spp. at $10 \mathrm{ppm}$. Further syntheses of DDK derivatives are being carried out in our laboratory.<smiles>COc1cc(CCc2ccccc2)oc(=O)c1</smiles>

(Dihydro-5,6-dehydrokawain)<smiles>O=C(/C=C/c1ccccc1)Oc1cc(CCc2ccccc2)oc(=O)c1</smiles>

Compounds D1-D11

$\mathrm{D} 1: \mathrm{R}=\mathrm{H}$

$\mathrm{D} 2: \mathrm{R}=o-\mathrm{Me}$

D3: $\mathrm{R}=m-\mathrm{Me}$

D4: $\mathrm{R}=p-\mathrm{Me}$

D5: $\mathrm{R}=p$-iso-Pro

D6: $\mathrm{R}=O-\mathrm{Cl}$

D7: $\mathrm{R}=m-\mathrm{Cl}$

D8: $\mathrm{R}=p-\mathrm{Cl}$

D9: $\mathrm{R}=o-\mathrm{F}$

D10: $\mathrm{R}=m-\mathrm{F}$

$\mathrm{D} 11: \mathrm{R}=p-\mathrm{F}$

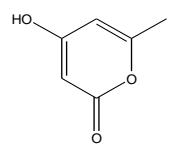

HMP

(5-Hydroxy-6-methyl-2H-pyran-2-one)

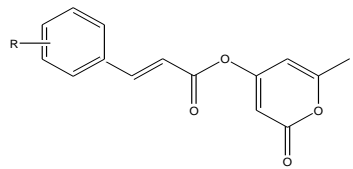

Compounds H1-H11

$\mathrm{H} 1: \mathrm{R}=\mathrm{H}$

$\mathrm{H} 2: \mathrm{R}=o-\mathrm{Me}$

$\mathrm{H} 3: \mathrm{R}=m-\mathrm{Me}$

$\mathrm{H} 4: \mathrm{R}=p-\mathrm{Me}$

H5 $\mathrm{R}=p$-iso-Pro

H6: $\mathrm{R}=O-\mathrm{Cl}$

$\mathrm{H} 7: \mathrm{R}=m-\mathrm{Cl}$

$\mathrm{H} 8: \mathrm{R}=p-\mathrm{Cl}$

$\mathrm{H} 9: \mathrm{R}=o-\mathrm{F}$

H10: $\mathrm{R}=m-\mathrm{F}$

H11: $\mathrm{R}=p-\mathrm{F}$

Figure 1. Structures of DDK, HMP and the Pyranyl - substituted Cinnamates. $[11,66]$

\section{Effort to utilize rice allelopathy for rice weed control}

Reducing weed infestation by exploiting the allelopathic properties of rice may be the most important goal of research involved in rice allelopathy and has been a hope of many agronomists. The direct use of rice residues and genetic control of rice allelopathy via breeding programmes to enhance weed suppression may be the most feasible strategy.

Allelopathic activity has been shown to be variety-dependent and origin-dependent, where Japonica rice shows greater allelopathic activity than Indica and Japonica-Indica hybrid. 
Extensive efforts of researchers worldwide to clarify allelopathic activities among rice cultivars have been made. They provided important information for further work such as genetic analyses, gene mapping of allelopathic characteristics and breeding new rice cultivars with strengthened weed suppression ability [10].

\subsection{Rice residue}

Utilization of rice residues in paddy fields has long been recognised as an important source to improve the organic matter status of soil and was also reported to reduce the emergence of weeds. In Asia, farmers are often left with a large amount of rice residues, leaves, stubble and straw in the paddy fields after harvest. Incorporating the residues of rice with high allelopathic activity minimised rice flatsedge (Cyperus iria L.) growth to a similar degree as achieved by the application of propanil and bentazon herbicides [69]. Furthermore, another trial showed residues of rice (var. Sarjoo 52) blended into the soil (5-6 cm in depth, 5 tons ha-1) suppressed jungle rice [Echinochloa colona (L.) Link], monarch redstem (Ammania baccifera L.), Ammania multiflora Roxb., and gulf leaf flower (Phyllanthus fraternus Webster) [70]. Other experiments reported that rice straw suppressed the germination of oat (Avena sativa) and wheat (Triticum aestivum), Lens sp., Convolvulus arvensis L., Avena ludoviciana and Phalaris minor Retz [71-72].

To date, decomposition of rice straw and stubble has reduced the occurrence of both broadleaved and grassy weeds [73]. Leaf plus straw and hulls of some rice cultivars with strong allelopathic property dramatically inhibited weed interference about $60-95 \%$ [74]. A pot study of soil incorporation of a mixture of stubble and straw in $15 \mathrm{~cm}$ of soil in the pots ( 7.4 tons ha ${ }^{-1}$ of blended stubble and straw) revealed inhibition on growth of weed density and decrease of the dry biomass of weeds [73]. Straw, leaves and hulls of some rice cultivars suppressed the germination of field bind weed (Convolvulus arvensis) and little seed canary grass (Phalaris minor) [71-72, 75-76]. Similarly, Pheng et al (2010) [77] suggested that if the rice residue incorporation was suspended for 2 weeks or only a proportion of the residue was incorporated, the rice crop could withstand the growth-suppressive effect. This research suggests that rice possessing high allelopathy can control some weeds in rice and can be integrated with existing weed management practice. Residues of rice allelopathy may be helpful for weed control, but they sometimes cause trouble with rice autotoxicity. From the residual effects of decomposing rice plant materials, the rice plant may obtain adaptive mechanisms to prevent a severe autotoxic effect. Forinstance,Chou,(1980) [78] reported in Taiwan that decomposed riceresidueslefton the paddy field soil persisted into thenext crop season and could reduce the riceyield by up to $25 \%$ compared with that of the first crop. Such a reduction was suggested to be primarily attributable to the phytotoxins produced, which inhibited paddy weed growth and minimised rice yield. Singh et al.(1999)[79]reported thatautotoxicityin ricecould provideanadaptivestrategy toplantsbecause they are grown in adequately water-logged soils sufficient in oxygen and thus develop a negative redox potential in soil because of decomposing rice residues. This induced the inhibition of root growth of rice plants accompanied by swelling of root cells in order to capture more oxygen [80]. Rice hulls and bran were reported to suppress paddy weeds and could be exploited for weed management [81]. Xuan et al. (2003) [52] noted that rice hulls and bran each at 1 ton ha-1 re- $^{-}$ duced paddy weed biomass by about $25 \%$ and $50 \%$, respectively. The combination of rice by- 
products and alfalfa strengthened weed suppression by $70-80 \%$ and controlled more weed species and increased rice yield more than the incorporation of single rice by-products.

\subsection{Molecular research in rice allelopathy and breeding}

Allelopathy is one of the last areas of plant science to use molecular biology as a tool in understanding the phenomena. Allelopathic competition, which may be defined as the unequal sharing of resources such as nutrition, light and water, is dependent on several physiological and phenological traits, and its allelopathy is polygenic and quantitatively inherited [82-84]. To be able to breed a more competitive crop with strong allelopathic potential, it is crucial to know which genes are involved in crop competitiveness and allelopathic potential. Molecular marker-aided genetics is presently the best tool for identifying quantitative traits, mapping the genes involved onto the chromosomes with a reasonable level of precision and analysing the relationship between the traits of interest and other important agronomic traits [82]. Allelopathic activity in rice has demonstrated to be a polygenic trait that is only slightly correlated with yield or other agronomic features. The quantitative inheritance of rice allelopathy curbed the breeding of allelopathic rice cultivars against paddy weeds under varying environmental condition [84, 86-87]. Recent research of Xu et al 2012 [85] has provided the evidence that diterpenoid momilactones (allelochemical) isolated from a rice cultivar plays a novel genetic for natural product-mediated allelopathy and furnished a molecular target for breeding and metabolic engineering of a rice cultivar. The selection of rice cultivars with strong weed suppression ability through transgenic and breeding programmes may successfully utilise rice allelopathy for weed control. Allelopathic activity of rice varies among cultivars and origins and correlates with some growth characteristics; therefore, the existence of genes determining rice allelopathy is presumed and should be detected. It was proposed that allelopathic activity may be a polygenic trait slightly correlated with yield or other agronomic features. Allelopathic potential in rice was demonstrated to be quantitatively inherited, but the allelopathic traits were not identified [83].

\subsection{Genomic analysis and gene mapping}

Despite research on rice allelopathy beginning in the early 1970s, the genetic allelopathy control programme started only in 1996 [88]. Dilday et al. (1998) [89] crossed the allelopathic rice cultivar PI312777 (PI) with another non-allelopathic rice cultivar Lemont and noted that the F2 was allelopathic against Heteranthera limosa and was quantitatively inherited. Jensen et al. (2001) [90] studied quantitative trait loci (QTLs) mapping using a population of 142 recombinant inbred lines (RILs) derived from a cross between IAC 165 (Japonica upland cultivar) and CO 39 (Indica irrigated cultivar). Four main QTLs located on three chromosomes, 2, 3 and 8, were identified and claimed $35 \%$ of the total phenotypic variation of the allelopathic activity against barnyardgrass. Okuno \& Ebana (2003) [91] identified seven QTLs controlling rice allelopathy on chromosomes 1, 3, 5, 6, 7, 11 and 12. Digenic interactions in five pairs among the seven QTLs were detected. This study showed 125 out of 215 restriction fragment length polymorphism (RFLP) generated polymorphic bands between PI312777 and Rexmont under QTL analysis. A map of 12 linkage groups was constructed and covered 
a genetic distance of $1336.2 \mathrm{cM}$. The total number of probes ranged from $12.7 \%$ to $76.4 \%$ among 12 chromosomes. With RFLP marker loci to the allelopathic QTLs at all pinpoints, the PI312777 alleles were more suppressive against lettuce than the Rexmont alleles. The positive allelopathic effect was shown by QTL located on chromosome 7 that suppressed root growth and necrosis on lettuce [92]. Zeng et al. (2003) [93] used a double-haploid population derived from ZYQ8/JX17, a typical Indica and Japonica hybrid. Four QTLs correlated to allelopathy belonging to chromosomes 3, 9, 10 and 12 were detected and their logarithm of odds scores were 3.40, 2.68, 2.75 and 3.08, respectively. Among them, additive effects of the QTLs on chromosomes 3 and 10 were 1.65 and 1.43 and on chromosomes 9 and 12 were -1.44 and 1.58, respectively. Recently, Lee et al. (2005) [94] identified nine QTLs controlling allelopathic effects of rice on E. crusgalli on chromosomes 1, 2, 3, 4, 5, 8, 9 and 12. Of these, QTLs on chromosomes 1 and 5 were the most allelopathic and explained $36.5 \%$ of total phenotypic variation. Lin et al. (2005) [95] used the inter-simple sequence repeat approach to detect the genetic diversity of allelopathic potential in 57 rice cultivars. Thirty-four polymorphic bands were generated, and the percentage of polymorphic bands was 53.0\%. Rice from the same geographical location and those cultivars with higher allelopathic potential could be clustered into each group, implying that the genes conferring allelopathy in rice might be isolocus. However, some cultivars of rice with markedly different allelopathic potential clustered into a group with a lower level of genetic polymorphism, and this might be attributed to selection oriented for high-yielding traits in breeding. More recent advances in rice genome research have provided a powerful tool for the genetic analysis of quantitative traits. The use of high density genetic linkage maps and DNA markers mapped onto rice chromosomes may enable the identification of the QTLs controlling the allelopathic effect of rice on weeds [96]. QTL analysis is the initial step in rice genetic analysis. Identification of QTLs from close linkage of a DNA marker to the QTL would be useful for producing near-isogenic lines. Application of DNA marker-assisted selection, map based cloning of allelopathic QTLs and a nearisogenic line may help to determine allelopathy-correlated genes in rice. Nine possible differently expressed genes 1, 4, 5, 7, 8 and 9 involved in allelopathic potential of Indica type rice variety, namely Sathoi, capable of producing nicotianamine against growth of barnyardgrass indicated higher while three differentially expressed genes 2, 3 and 6 showed low expression. It implies that these genes were found to be homologous to other genes [96-98]. To date, under low-nitrogen stress, rice cultivar PI exhibited increased allelopathic activity. Nine genes involved in phenylpropanoid metabolism, including phenylalanine ammonialyase (PAL), became up regulated and the content of phenolic compounds in rice was enhanced [98-99]. Song et al. (2008) [101] reported that the intensification of allelochemical biosynthesis in rice grown under stress nutrition (i.e., low levels of nitrogen) disclosed the overexpression of genes that encode for PAL (phenylalanine ammonia-lyase), O-methyltransferase, triosephosphate isomerise and P450-all related to the synthesis of phenolic compounds and detoxification. Furthermore, a proteomic analysis of rice growing with barnyardgrass revealed the induction of the following proteins: PAL, a thioredoxin and 3hydroxy-3-methilglutaril-coenzyme a reductase 3 (HMGR) [102]. On the other hand, the differential proteomic analyses have validated that enhanced allelopathic potential in rice exposed to stress is due to increased expression of enzyme genes involved in the biosynthe- 
sis of phenolic compounds and reduced expression of enzyme genes associated with terpenoid biosynthesis [103]. The identification of these genes and proteins shows different signs, plantenvironment interactions or plant-plant communication triggering the biosynthesis of phenolic compounds that are also known to be related with plant defence processes [102,104]. Moreover, allelopathic enhancement of allelopathic rice cultivars in the vicinity of barnyardgrass was due to improvement in carbon assimilation deriving from the regulation of photosynthesis genes and the activation of the enzyme system [103, 105].

\subsection{Breeding new rice allelopathic cultivars}

To breed new rice cultivars having strong competitiveness against weeds may bring important benefits to farmers in rice-cultivating nations. In the breeding programme, both traditionally bred and hybrid rice with allelopathy may be feasible. Courtois \& Olofsdotter (1998) [88] indicated that if a high number of QTLs with low effect are involved, a traditional breeding method can be a reasonable alternative, in which two parents with contrasting behaviour are crossed and RILs are derived through the single seeded descent method (SSD). Kim \& Shin (2003) [106] crossed Donginbyeo (a non-allelopathic cultivar, but a high yielding rice of good quality) and Kouketsumochi (an allelopathic cultivar, close to a wild type) and advanced by SSD breeding method. The F5 of this cross exhibited allelopathic potential in bioassays and was continuously examined under field conditions. The three-line hybrid rice widely cultivated in China may be a good source because of its rapid and profuse vegetative growth in comparison with an inbred line [106]. Lin et al. (2000) [107] applied a simultaneous backcrossing and selfbreeding method to develop a hybrid rice with allelopathic activity and, its counter-part, an isogenic hybrid rice with no allelopathic effect on weeds. Three lines of rice Kouketsumochi, Rexmont and IR24 were used as the allelopathic donors, non-allelopathic and restoring genes, respectively. The selected restorer lines were crossed with cytoplasm-sterile lines and tested for the outcross rate. This work illustrated a scheme for developing hybrid rice having allelopathic potential. On the other hand, the heterotic effect on rice allelopathy was positively significant, showing higher heterosis over the mid-parent. This specific hybrid rice showed a suppressive effect on barnyardgrass, exhibiting a large deviation from the resource competition curve [107]. Hybrid rice with stronger weed suppression ability could be bred, but the quality factors associated with rice allelopathy should be carefully considered in the breeding programme as an important standard for the new cultivars. A newly bred rice, namely K21 showed highly allelopathic and agronomically fit. This cultivar inherited its good agronomic performance from the female parents (Dongibyeo) and attained its potent allelopathic potential from male parent (Koutetsumochi) [108-109]. Moreover, Kim and Shin, 2008 [108] suggested that identified allelochemicals and genes which responsible for allelopathic activity can further be incorporated into the cultivars via breeding or genetic engineering. For instance, the diterpenoid momilactones and phenolics in rice work as the major inhibitor substances to suppress weeds, which are able to be produced in a conventional rice cultivar by inserting the genes CA4H and OsDTS2 for $p$-coumaticacid and momilactone, respectively through geneticengineering or even conventional breeding [108, 85, 103]. Also, Kong et al. 2011 [84] has successfully developed commercially acceptable allelopathic rice cultivars via crosses between allelopathic rice variety PI12777 and 
commercial cultivars. The bred Huagan-3 showed $80 \%$ inhibition on noxious barnyardgrass and $30-50 \%$ of a total reduction in paddy weeds. However, it should be noted that developing allelopathic rice cultivars must therefore be accompanied with an evaluation of the cultural practices required for consistent suppression under variable environmental conditions [84, 86]. On the other hand, before starting any plant breeding program to enhance allelopathic activity, it is important to utilize a practical effective screening method in both controlled and natural conditions for measurement of allelopathic potential. It is hoped that with assistance of modern genetic techniques, new rice cultivars with strong weed suppression ability and acceptable for cultivation by farmers will hopefully appear very soon.

\section{Benefits from allelopathy integrated into sustainable agriculture}

If allelopathy can be integrated into sustainable agriculture appropriately, the heavy dependence on synthetic pesticides and other agrochemicals can be significantly minimized. Mono culture has caused imbalances in agricultural production, and this would be replaced by a more ecological and sustainable cropping system. In modern agriculture with its shortage of labour, it is difficult to completely alter the use of agrochemicals, but the biological characteristics of crops including allelopathy and strength of competition should be exploited to reduce the amount of pesticides and agrochemicals used. Furthermore, unsafe pesticides and agrochemicals must be replaced by safer bioactive products, which are derived from living organisms such as plants, fungi, bacteria, and micro-organisms. The detrimental effects from allelopathy integration into agricultural production should also be noted, as only their benefits have been detailed [37]. The competition and chemical interaction of crops can effectively inhibit weeds and other pests, but they may also have harmful effects for crops in the next cropping seasons. Allelochemicals released from living plants and decomposition includes many toxins, which may suppress growth of useful bacteria, fungi, and micro-organisms, but they may cause problems to mineralization and nitrification in soils. This issue can be excluded with common crops, but should be examined when plant (other than common crops and legumes) materials are incorporated into soils. This style of application is still useful in many developing countries, in which a major proportion of the population is still involved in agricultural production. The modes of action of allelochemicals need further research to exploit novel allelochemicals and their derivatives in the development of bioactive pesticides. However, in addition, the extent to which they cause detrimental effects to crops and soils needs careful examination. Despite the fact that many hypotheses have been developed and discussed, and many experiments have been carried out to test them, the actual modes of action of allelopathy in nature are still somewhat unclear, unlike the allelopathic phenomena that we could easily observe. The allelopathic characteristics of plants have been known for centuries, and extensive research worldwide has been conducted for more than 40 years to elucidate the mode of allelopathy as well as efforts to utilize allelopathy more effectively in agricultural production. However, it can be said that farmers have not yet received much efficacy from what has been observed and reported. Much knowledge on plant allelopathy has been documented, but few approaches have already been successfully applied in agricultural 
practice. There is no doubt that organic and sustainable agricultural practices are indispensable forms of resource management, with the source of knowledge being traditional agriculture throughout the world $[37,110]$. What we have researched and discussed about multiple cropping, the use of cover crops, organic compost, and biological controls of pests has been traditionally conducted by farmers without knowledge of allelopathy. Therefore, our achievements on allelopathy should be carefully incorporated with the traditional practices of farmers to create sustainable agriculture integrated with allelopathy. Otherwise, this system will never be feasible for farmers to adopt for economic reasons and in the complex ecological conditions of the tropics, these practices would be inappropriate [110]. In our modern agriculture, ecological and sustainable factors are indispensable. Therefore, what crop species are used and how they are applied in the cropping system are important. Of which, both crop allelopathy and nutrient cycle should be further studied to enhance biological characteristics of crops in the agricultural production. The establishment of allelopathy-integrated sustainable agriculture is obviously varied among cultivating regions, of which opinions of farmers regarding traditional cropping system should be referred, and should be carefully examined and repeated before introducing to farmers for agricultural practices. An agricultural production that is sustainable, economical, less labour-intensive, can be easily implemented by farmers, and supported by local authorities could be helpful for farmers in developing countries to eliminate poverty. To date, a number of phytotoxins involved in the allelopathic activities of worldwide rice cultivars have been identified and isolated, and the fate of these compounds in the environment has been gradually understood, and mode of allelopathy is therefore much clearer. Many novel secondary metabolites have been synthesized and marketed as bioactive pesticides, which effectively aid the integration of sustainable agriculture with allelopathy. The use of allelopathy as a tool for a more bio-rational management of natural resources is not a simple panacea for the solution of ecological problems in agroecosystems or in natural ecosystems. It is necessary to develop a scientific approach based on the disciplines of botany, ecology, chemistry, microbiology, agronomy, entomology, and biochemistry, and to work together to clarify these bio-chemical interactions from a holistic point of view, as well as utilize them for beneficial purposes in the management of natural resources in agro-ecosystems $[37,110]$. The application of crop rotation, cover crop, mulch, green manure, and incorporation of plant materials with strong allelopathic potential may be more effective in the agricultural practice. The integration of allelopathy via breeding and/or genetic manipulation in rice cultivars may clearly provide specific opportunities for successful implementation of alternative weed management systems [111]. However, knowledge about allelopathy for weed and pest management and establishment of sustainable agriculture integrated with allelopathy should be further introduced to local extension workers and farmers. The modification of allelopathy-integrated sustainable agriculture is needed to allow it to be suitable for different regions. Undoubtedly, the integration of allelopathy in rice will benefit from worldwide collaboration with ecologists, plant breeders, and molecular biologists leading to the successful utilization of new tools for selection of rice cultivars with weedsuppressive traits. 


\section{Author details}

T.D. Khanh ${ }^{1}$, L.H. Linh ${ }^{1}$, T.H. Linh ${ }^{1}$, N.T. Quan ${ }^{1}$, D.M. Cuong1, V.T.T. Hien ${ }^{1}$, L.H. Ham ${ }^{1}$, K.H. Trung ${ }^{1}$ and T.D. Xuan ${ }^{2 *}$

*Address all correspondence to: tdxuan@hiroshima-u.ac.jp; khanhkonkuk@gmail.com

1 Department of Molecular Biology, Agricultural Genetics Institute, Vietnam

2 Graduate School for International Development and Cooperation (IDEC), Hiroshima University, Japan

\section{References}

[1] Khanh TD, Chung IM, Xuan TD, Tawata S. The exploitation of crop allelopathy in sustainable agricultural production. Journal of Agronomy and Crop Science 2005; 191 172-184.

[2] Olofsdotter M, Navarez D, Moody K. Allelopathy potential in rice (Oryza sativa L.) germplasm. Annals of Applied Biology 1995; 127 543-560.

[3] Molisch H. Der Einfluss einer Pflanze auf die andere-Allelopathie. Jena, Germany: Gustav Fischer; 1937.

[4] Rice EL. Allelopathy. Physiological Ecology. New York, NY: Academic Press; 1974.

[5] Romeo JT, Weidenhamer JD. Bioassays for allelopathy in terrestrial plants. In: Eds. Haynes KF and Millar JG. (eds.) Methods in Chemical Ecology. MA: Kluwer Academic Publishing; 1999. p179-211.

[6] Rice EL. Allelopathy. Physiological Ecology. Orlando, FL: Academic Press; 1984

[7] An M, Pratley JE, Haig T, Jellett P. Genotypic variation of plant species to the allelopathic effect of vulpia residues. Australian Journal of Experimental Agriculture 1997; 37 647-660.

[8] Shibayama H. Weeds and weed management in rice production in Japan. Weed Biology and Management 2001 153-60.

[9] Olofsdotter M, Navarez D, Rebulanan M, Streibig JC. Weed suppressing rice cultivars-does allelopathy play a role? Weed Research 1999; 39 441-454.

[10] Khanh TD, Xuan TD, Chung IM. Rice allelopathy and the possibility for weed management. Annals of Applied Biology 2007; 151 324-339.

[11] Khanh TD, Elzaawely AA, Chung IM, Ahn JK, Tawata S, Xuan TD. Role of allelochemicals for weed management in rice. Allelopathy Journal 2007; 19 85-96. 
[12] Baltaza AM and Dedatta SK. Weed management in rice. Weed abstract 1992. 41 495-497.

[13] Aliotta G, Cafiero G, Otero AM. Weed germination, seedling growth and their lesson from allelopathy in agricultural. In: Reigosa MJ, Redrol N, Gonzales L. (eds.) Allelopathy: A Physiological Process with Ecological Implications. Dordrecht, the Netherlands: Springer Publisher; 2006. p 285-299.

[14] Holm LG, Plucknett DL, Pancho JV, Herberger JP. The World's Word weeds distribution and biology. The University Press of Hawaii: Honodulu; 1991. p 609.

[15] McIntyre S, Finlayson CM, Ladiges PY, Mitchell DS. Weed community composition and rice husbandry practices in New South Wales, Australia. Agriculture, Ecosystems and Environment 1991; 34 27-45.

[16] Heap IM. The occurrence of herbicides-resistant weeds worldwide. Pesticide Science $1997 ; 51235-243$.

[17] Anaya AL. Allelopathic organisms and molecules: promising bio-regulators for the control of plant diseases, weeds, and other pests. In: Inderjit, Mukerji KG. (eds.) Allelochemicals: Biological Control of Plant Pathogens and Diseases. Springer Dordrecht: The Netherlands; 2006. p 31-79.

[18] IFIC. International Food Information Council. Agriculture and Food Production, Background on Agriculture and Food Production; 2007. http://www.ific.org/ food/ agriculture/index.cfm (accessed 25 November 2012).

[19] Kohli RK, Batish D, Singh HP. Allelopathy and its implication in agroecosystems. Journal of Crop Production 1998; 1 169-202.

[20] Worsham AD. Current and potential techniques using allelopathy as an aid in weed management. In: Chou CH, Waller GR. (eds.) Phytochemical Ecology: Allelochemical, Mycotoxins and Insect Pheromones and Allomones. Monograph Series, No. 9, Institute of Botany, Academia Sinica, Taipei, ROC; 1989. p 275-89.

[21] Duke SO, Dayan FE, Rimando AM. Natural products and herbicide discovery. In: Cobb HS, Kirkwood RC. (eds.) Herbicides and their Mechanism of Action. Sheffield Academic Press, Sheffield: UK; 2000. p 105-33.

[22] Mitchell G, Bartlett DW, Fraser TEM, Hawkes TR, Holt DC, Townson JK et al. Mesotrione: a new selective herbicide for use in maize. Pest Management Science 2001; 57 20-28.

[23] Mamolos AP, Kalburtji KL. Significance of allelopathy in crop rotation. Journal of Crop Production 2001; 4 197-218.

[24] Lampkin L. Organic Farming. Farming Press, Ltd, Ipswich: UK; 1994. 
[25] Horst WJ, Haerdter R. Rotation of maize with cowpea improves yield and nutrition use of maize compared to maize monocropping in an alfalfa soil in Northern Guinea Savanna of Ghana. Plant and Soil 1994; 160 171-183.

[26] Kessavalou A, Walters DT. Winter rye as a cover crop following soybean under conservation tillage. Agronomy Journal 1997; 89 68-74.

[27] Patrick ZA, Koch LW. 1963 The adverse influence of phytotoxic substances from decomposing plant residues on resistance of tobacco to black root rot. Canadian Journal of Botany 1963; 41 747-758.

[28] Chou CH. Allelopathy in relation to agricultural productivity in Taiwan: problems and prospects. In: Rizvi SJH, Rizvi V. (eds.) Allelopathy: Basic and Applied Aspects. Chapman and Hall: London; 1992. p 179-204.

[29] Johnson AW. Specific crop rotation effects combined with cultural practices and nematicides. In: Sasser JN, Carter CC. (eds.) An Advanced Treatise on Meloidogyne. North Carolina State University Press: Raleigh NC; 1985. p283-301.

[30] Rizvi SJH, Rizvi V. Exploitation of allelochemicals in improving crop productivity. In: Rizvi SJH, Rizvi V. (eds.) Allelopathy, Basic and Applied Aspects. Chapman and Hall: London; 1992. p 443-73.

[31] Narwal SS. Allelopathy in ecological sustainable agriculture. In: Reigosa MJ, Pedrol N, Gonzalez L. (eds) Allelopathy - A Physiological Process with Ecological Implications. Springer Dordrecht: The Netherlands; 2006.p 512-37.

[32] Batish DR, Singh HP, Kohli RK, Kaur S. Crop allelopathy and its role in ecological agriculture. Journal of Crop Production 2001; 4 121-62.

[33] Swanton CJ, Murphy SD. Weed science beyond the weeds: the role of integrated management (IWM) in agroecosystem health. Weed Science 1996; 44 437-445.

[34] Gallandt ER, Liebman M, Huggins DR. Improving soil quality: implications for weed management. Journal of Crop Production 1999; 2 95-121.

[35] Fageria NK, Baligar VC, Bailey BA. Role of cover crop in improving soil and row crop productivity. Communications in Soil Science and Plant Analysis 2005; 262733 2757.

[36] Worsham AD, Blum U. Allelopathic cover crops to reduce herbicide inputs in cropping systems. In: Richardson RG. (ed.) Proceedings of the First International. Weed Control Congress. Weed Science Society of Victoria : Melbourne,VIC Australia; 1992. p 577-579.

[37] Khanh TD, Chung IM, Tawata S, Xuan TD. Allelopathy for weed management in sustainable agriculture. CAB Reviews: Perspectives in Agriculture, Veterinary Science, Nutrition and Natural Resources 2007; 2 (034). 
[38] Foley MC. Genetic approach to the development of cover crops for weed management. Journal of Crop Production 1999; 2(1) 77-93.

[39] Frick B, Johnson E. Using allelopathic and cover crops to suppress weeds. Research Report - Scott Research Farm; 2002. p. 125-126.

[40] Boydston RA, Al-Khatib K, Hang A, Krishnan G, Nissen S. Weed control with rapeseed (Brassica napus) and white mustard (Brassica hirta) as green manure crops. Weed Science Society of American, Abstract 1994; 3489.

[41] Al-Khatib K, Boydston R. Weed control with Brassica green manure crop. In: Narwal SS. (ed.) Allelopathy Update, Vol. 2. Basic and Applied Aspects. Oxford and IBH: New Delhi, India; 1999. p 255-227.

[42] Kohli RK, Batish DR, Singh HP. Allelopathic interactions in agroecosystems. In: Reigosa MJ, Pedrol N, Gonzalez L. (eds.) A Physiological Process with Ecological Implication. Springer; 2006. p 465-493.

[43] Nava RV, Fernandez LE, Del Amo RS. Allelopathic effects of green fronds of Pteridium aquilinum on cultivated plant, weeds, phytopathogenic fungi and bacteria. Agriculture, Ecosystems and Environment 1987;18 357-379.

[44] Hartwig NL, Hoffman LD. Suppression of perennial legume and grass cover crop for no-tillage corn. Proceedings of the Northeastern Weed Science Society 1975; 29 82-88.

[45] Vaughan SF, Boydston RA. Volatile allelochemicals released by crucifer green manures. Journal of Chemical Ecology 1997;23 2107-2116.

[46] Bantilan RT, Palada MC, Harwood RK. Integrated weed management. I. Key factors affecting crop weed balance. Philippines Weed Science Bulletin 1974; 1 14-36.

[47] Gliessman SR. Allelopathy and agricultural sustainability. In: Chou CH, Walter GR. (eds.) Phytochemical Ecology: Allelochemicals, Mycotoxins, Insect Pheromones and Allomones. Monograph No. 9. Institute of Botany Academia Sinica: Taipei, Taiwan; 1989. p 69-80.

[48] Xuan TD, Tawata S, Khanh TD, Chung IM. Biological control of weeds and plant pathogens in paddy rice by exploiting plant allelopathy: an overview. Crop Protection 2005;24 197-206.

[49] Khanh TD, Xuan TD, Chin DV, Chung IM, Elzaawely AA, Tawata S. Current status of biological control of paddy weeds in Vietnam. Weed Biology and Management 2006; $61-9$.

[50] Hong NH, Xuan TD, Tsuzuki E, Khanh TD. Paddy weed control by higher plants from South East Asia. Crop Protection 2004; 23 255-261.

[51] Khanh TD, Hong NH, Xuan TD, Chung IM. Paddy weed control by medicinal leguminous plants from Southeast Asia. Crop Protection 2005; 24 421-431. 
[52] Xuan TD, Tsuzuki E, Terao H, Matsuo M, Khanh TD. Alfalfa, rice by-products, and their incorporation for weed control in rice. Weed Biology and Management 2003; 3 137-144.

[53] Xuan TD, Tsuzuki E, Terao H, Matsuo M, Khanh TD, Chung IM. Evaluation on phytotoxicity of neem (Azadirachta indica. A. Juss) to crops and weeds. Crop Protection 2004; 23 335-345.

[54] Xuan TD, Tsuziki E, Tawata S, Khanh TD. Methods to determine allelopathic potential of crop plants for weed control. Allelopathy Journal 2004; 13 149-164.

[55] Xuan TD , Tsuzuki E. Effects of application of alfalfa pellet on germination and growth of weeds. Journal of Crop Production 2001; 4 303-312.

[56] Khanh TD, Chung IM, Tawata S, Xuan TD. Weed suppression by Passiflora edulis and its potential allelochemicals. Weed Research 2006; 46 296-303.

[57] Xuan TD, Tawata S, Hong NH, Khanh TD, Chung IM. Assessment of phytotoxic action of Ageratum conyzoides L. (billy goat weed) on weeds. Crop Protection 2004; 23 335-345.

[58] Deba F, Xuan T D, Yasuda M, Tawata S. Herbicidal and fungicidal activities and identification of potential phytotoxins from Bidens pilosa. var. Radiata. Weed Biology and Management 2007; 7 77-83.

[59] Xuan TD, Tsuzuki E, Matsuo M, Khanh TD. Correlation between inhibitory exhibition and suspected allelochemicals in alfalfa (Medicago sativa L.). Plant Production Science 2003; 6 165-171.

[60] Xuan TD, Tawata S, Khanh TD, Chung IM. Decomposition of allelopathic plants in soil. Journal of Agronomy and Crop Science 2005; 191 162-171.

[61] Khanh TD, Hong NH, Nhan DQ, Kim SL, Chung IM, Xuan TD. Herbicidal activity of Stylosanthes guianensis and its phytotoxic components. Journal of Agronomy and Crop Science 2006; 192 427-433.

[62] Chung IM, Kim JT, Kim SH. Evaluation of allelopathic potential and quantification of momilactone A, B from rice hull extracts and assessment of inhibitory bioactivity on paddy field weeds. Journal of Agricultural and Food Chemistry 2006; 54 2527-2536.

[63] Xuan TD, Elzaawely AA, Fukuta M, Tawata S. Herbicidal and antifungal activities of lactones in kava (Piper methysticum). Journal of Agricultural and Food Chemistry 2006; 54 720-725.

[64] Xuan TD, Elzaawely AA, Deba F, Fukuta M, Tawata S. Mimosine as a potent herbicide. Agronomy for Sustainable Development 2006; 26 89-97.

[65] Duke SO, Dayan FE, Romagni JG, Rimando AM. Natural products as sources of herbicides: current status and future trends. Weed Research 2000; 40 99-111. 
[66] Zhu J, Majikina M, Tawata S. Syntheses and biological activities of pyranyl-substituted cinnamates. Bioscience Biotechnology and Biochemistry 2001; 65 161-163.

[67] Tawata S, Taira S, Kobamoto S, Ishihara M, Toyama S. Syntheses and biological activities of dihydro-5,6-dehydrokawain derivatives. Bioscience Biotechnology and Biochemistry 1996; 60 1643-1645.

[68] Tawata, S., Taira, S., Kobamoto, N., Zhu, J., Ishihara, M. and Toyama, S. (1996). Synthesis and antifungal activity of cinnamic acid esters. Bioscience Biotechnology and Biochemistry 60: 909-910.

[69] Lin J Jr, Smith RJ, Dilday RH. Allelopathic activity of rice germplasm on weed. Proceedings in Southern Weed Science Society; 19924599.

[70] Khan AH, Vaishya RD. Allelopathic effects of different crop residues on germination and growth of weeds. In: Tauro P, Narwal SS.(eds.) Proceedings of National Symposium on Allelopathy in Agroecosystem, 12-14 February 1992, CCS Haryana Agricultural University. Hisar, India: Indian Society of Allelopathy; 1992.p 59-60.

[71] Young CC, Zhu C, Throne LR, Waller GR. Phytotoxic potential of soils and wheat straw in rice rotation cropping systems of subtropical Taiwan. Plant Physiology 1989; 120 95-101.

[72] Tamak JC, Narwal SS, Singh L, Singh I. Effect of aqueous extract of rice stubble and straw + stubble on the germination and seedling growth of wheat, oat, berseem and lentil. Crop Research 1994; 8 180-185.

[73] Narwal SS. Weed management in rice: wheat rotation by allelopathy. Critical Reviews in Plant Science 2000; 19 249-266.

[74] Jung WS, Kim KH, Ahn JK, Hahn SJ, Chung IM. Allelopathic potential of rice (Oryza sativa L.) residues against Echinochloa crus-galli. Crop Protection 2004; 23 211-218.

[75] Ahn JK, Chung IM. Allelopathic potential of rice hulls on germination and seedling growth of barnyard grass. Agronomy Journal 2000; 92 1162-1167.

[76] Inderjit, Rawat D, Foy CL. Multifaceted approach to determine rice straw phytotoxicity. Canadian Journal of Botany 2004; 82 168-176.

[77] Pheng S, Olofsdotter M, Jahn G, Adkins S. Use of phytotoxic crop residues for weed management. Weed Biology and Management 10; 176-184

[78] Chou CH. Allelopathic researches in subtropical vegetation in Taiwan. Comparative Physiology and Ecology 1980; 5: 222-234.

[79] Singh HP, Daizy R, Batish DR, Kohli RK. Autotoxicity: concept, organism, and ecological significance. Critical Reviews in Plant Science 1999; 18 757-772. 
[80] Chou CH. Allelopathy and sustainable agriculture. In: Inderjit, Dakshini KMM, Einhellig FA. (eds.) Allelopathy: Organisms, Processes and Application . ASC Symposium Series No. 582. Washington, DC: American Chemistry Society; 1995. p 211-223.

[81] Kuk YI. Evaluation of rice by-products for weed control. Weed Science 2001; 49 141147.

[82] Olofsdotter M. Getting closer to breeding for competitive ability and the role of allelopathy - an example from rice (Oryza sativa). Weed Technology 2001; 15 798-806.

[83] Olofsdotter M. Rice-a step toward use of allelopathy. Agronomy Journal 2001; 93 3-8.

[84] Kong $\mathrm{CH}$, Chen $\mathrm{XH}, \mathrm{Hu}$ F, Zhang SZ. Breeding of commercially acceptable allelopathic rice cultivars in China. Pest Management Science 2011; 67 1100-1106.

[85] Xu M, Galhano R, Wiemann P, Bueno E, Tiernan M, Wu W, Chung IM, Gershenzon J, Tudzynski B, Sesma A, Peter RJ. Genetic evidence for natural product-mediated plant-plant allelopathy in rice (Oryza sativa). New Phytologist 2012; 193 570-575.

[86] Belz RG. Allelopathy in crop/weed interactions - an update. Pest Management Science 2007; 63:308-326.

[87] Dilday RH, Mattice JD, Moldenhauer AK. An overview of rice allelopathy in the USA. In: Kim KU, Shin DH. (eds.) Rice Allelopathy. Kyungpook National University, Taegu, Korea; 2000. p 15-26.

[88] Courtois B, Olofsdotter M. (1998) Incorporating the allelopathy trait in upland rice breeding program. In Pro-ceedings of Workshop on Allelopathy in Rice, 25-27 November 1996, Makati City, pp. 57-67. Ed M. Olofsdotter. Manila, The Philippines: International Rice Research Institute.

[89] Dilday RH, Yan WG, Moldenhauer AK, Gravois KA. Allelopathic activity in rice for controlling major aquatic weeds. In: Olofsdotter M. (ed.) Proceedings of the Workshop on Allelopathy in Rice, 25-27 November 1996, Makati City, Manila, The Philippines: International Rice Research Institute; 1998.p 7-26.

[90] Jensen LB, Courtois B, Shen L, Li Z, Olofsdotter M, Mauleon RP. Locating genes controlling allelo-pathic effects against barnyardgrass in upland rice. Agronomy Journal 2001; 93 16-21.

[91] Okuno K, Ebana K. Identification of QTL controlling allelopathic effects in rice: genetic approaches to biological control of weeds. Japan Agricultural Research Quarterly 2003; 37 77-81.

[92] Okuno K, Ebana K, Hegab M. Challenges for biological weed control using genetic diversity of rice-QTL and candidate compounds associated with allelopathic effect. CS2-S1, 5th International Crop Science Congress and Exhibition (ICSC 2008); 2008.

[93] Zeng DL, Qian Q, Teng S, Dong GJ, Fujimoto H, Yasufumi K, Zhu LH. Genetic analysis of rice allelopathy. Chinese Science Bulletin 2003; 48 265-268. 
[94] Lee SB, Seo KI, Koo JH, Hur HS, Shin JC. QTLs and molecular markers associated with rice allelopathy. In: Harper JDI, An M, Wu H, and Kent JH. (eds.) Fourth World Congress on Allelopathy "Establishing the Scientific Base”'Wagga Wagga, Australia: CharlesSturt University2005. p 505-507

[95] Lin WX, He HQ, Chen XX, Song BQ, Liang YY, Liang KJ. Use of ISSR molecular markers approach to estimate genetic diversity in rice and barley allelopathy. In: Harper JDI, An M, Wu H, Kent JH. (eds). Proceedings of World Fourth Congress on Allelopathy. Wagga Wagga, Australia: Charles Sturt University; 2005.p 168-174.

[96] Harushima Y, Yano M, Shomura A, Sato M, Shimano T, Kuboki Y, Yamamoto T, Lin SY, Antonio BA, Parco A, Kajiya H, Huang N, Yamamoto K, Nagamura Y, Kurata N, Khush GS, Sasaki T. A high-density rice genetic linkage map with 2275 markers using a single F2 population. Genetics 1998; 148 479-494.

[97] Junaedi A, Jung WS, Chung IM, Kim KH. Differentially expressed genes of potentially allelopathic rice in response against barnyardgrass. Journal of Crop Science and Biotechnology 2008; 10 231-236.

[98] Maqbool N, Wahid A, Farooq M, Cheema ZA, Siddique KHM. Allelopathy and abiotic stress interaction in crop plants. In: Allelopathy, Cheema ZA et al. (eds.) SpringerVerlag Berlin: Heidelberg 2013. P 451-468.

[99] Xiong J, Wang HB, Qiu L, Wu HW, Chen RS, He HB, et al. qRT-PCR analysis of key enzymatic genes related to phenolic acid metabolism in rice accessions (Oryza Sativa L.) exposed to low nitrogen treatment. Allelopathy Journal 2010; 25 345-356.

[100] Wang HB, He HB, Ye CY, Lu JC, Chen RS, Liu CH, et al. Molecular physiological mechanism of increased weed suppression ability of allelopathic rice mediated by low phosphorus stress. Allelopathy Journal 2010; 25 239-248.

[101] Song B, Xiong J, Fang C, Qiu L, Lin R, Liang Y, Lin W. Allelopathic enhancement and diferential gene expression in rice under low nitrogen treatment, Journal of Chemical Ecology 2008; 34 688-695.

[102] Lin W, He H, Shen L, Chen X, Ke Y, Guo Y, He H. A proteomic approach to analysing rice allelopathy on barnyard grass (Echinochloa crus-galli L.) Proceedings of the $4^{\text {th }}$ International Crop Science Congress, Brisbane: Australia; 2004 http://www.cropscience.org.au/icsc2004/poster/2/4/1/1414_xionglw.htm (accessed 26 November 2012).

[103] Jabran K, Farooq M. Implication of potential allelopathic crops in agricultural systems. In: Cheema ZA et al. (eds.) Allelopathy. Springer-Verlag : Berlin Heidelberg; 2013. p 349-385.

[104] De Albuquerque MB, Dos Santos RC, Lima LM, Melo Filho PA, Nogueira RJMC, Da Camara CAG, Ramos AR. Allelopathy, an alternative tool to improve cropping systems. A review. Agronomy for Sustainable Development 2011; 31 379-395. 
[105] He HQ, Shen LH, Xiong J, Jia XL, Lin WX, Wu H. Conditional genetic effect of allelopathy in rice (Oryza sativa L.) under different environmental conditions. Plant Growth Regul 2004; 44 211-221.

[106] Kim KU, Shin DH. The importance of allelopathy in breeding new cultivars. In: Labrada R. (ed.) Weed Management for Developing Countries. Addendum 1-FAO Plant Production and Protection Paper 120, Rome, Italy: Food Agriculture Organization of the United Nations; 2003. p 290.

[107] Lin W, Kim KU, Liang K, Guo Y. Hybrid rice with allelopathy. In Kim KU, Shin DH. (eds.) Rice Allelopathy, Proceedings of the International Workshop in Rice Allelopathy, 17-19 August 2000, Institute of Agricultural Science and Technology, Kyungpook National University, Taegu, Korea: Chan-Suk Park; 2000. p 49-56.

[108] Kim KU, Shin DH. Progress and prospect of rice allelopathy research. In: Zeng RS, Malik AU, Luo SM (eds.) Allelopathy in sustainable agriculture and forestry. Springer: The Netherlands; 2008. p 189-213.

[109] Ma HJ, Shin DH, Lee IJ, Koh JC, Park SK, Kim KU. Allelopathic K21 selected as promising allelopathic rice. Weed Biology and Management 2006; 6 189-196.

[110] Anaya AL. Allelopathy as a tool in management of biotic resources. Critical Reviews in Plant Sciences 1999;18 697-39.

[111] Bertin C, Weston LA, Kaur H. Allelopathic crop development: Molecular and traditional plant breeding approaches. In: Janick J. (ed.) Plant Breeding Review; 2008. p 231-254. 
